\title{
A Study on the Absorption Mechanism of Pentachlorophenol in Goldfish Relating to Its Distribution between Solvents and Water*1
}

\author{
Takuo Kishino*2 and Kunio KoBayashi*3 \\ (Received May 19, 1980)
}

\begin{abstract}
A study has been made of the absorption mechanism of pentachlorophenol (PCP) from media in goldfish, Carassius auratus, through examination of the relationship between the bioconcentration of PCP by the fish and the distribution of PCP in organic solvents/water partitioning systems at various $\mathrm{pHs}$.

The linear relationship was observed between the bioconcentration ratio of $\mathrm{PCP}$ in goldfish at 1-h exposure to $0.1 \mathrm{ppm} \mathrm{PCP}$ and the distribution ratio of PCP in both the systems of 1-cetanol/ water and 1-heptanol/water in the $\mathrm{pH}$ range from 5.5 to 10 , but not in nonpolar solvents/water systems, such as xylene, $n$-hexane and $n$-heptane.

The pH-dependent linear relationship between the bioconcentration ratio in the fish and the distribution ratio in the alcohol/water system demonstrates that the transfer of PCP from media to the fish is caused mainly by passive diffusion of the unionized form probably through the gill membrane. The reduction of the toxicity of PCP to the fish with an increase of the $\mathrm{pH}$ of media is attributed to the decrease of the concentration of the unionized PCP in the media by conversion into the ionized form, although the ionized PCP is slightly transferred to the fish presumably by hydrogenbonding with polar lipids which constitute the gill membrane.
\end{abstract}

Our preceding study ${ }^{12}$ which has been made of the effect of $\mathrm{pH}$ on the toxicity and accumulation of pentachlorophenol (PCP) in goldfish, Carassius auratus, elucidated that the absorption of PCP by the fish abruptly decreases with an increase of the $\mathrm{pH}$ or PCP-media, resulting in the reduction of the toxicity of PCP to the fish. It was also assumed that the decrease of PCP absorption is due to the change of the unionized PCP to the ionized form with an increase of the $\mathrm{pH}$ of media.

NEELY et $a l_{.}{ }^{2)}$ have found that the bioconcentration factors of several chemicals in trout muscle follow a straight line relationship with the partition coefficients of the chemicals in 1-octanol/ water system. Therefore, it is presumed that the change in the bioconcentration of PCP by goldfish with the variation in the $\mathrm{pH}$ of media, as shown in the preceding paper, ${ }^{1)}$ may be correlated with the change in the distribution of PCP in an organic solvent/water system at various $\mathrm{pH}$.

The present study was undertaken to elucidate the absorption mechanism of PCP from media in goldfish through examination of the relationship between the bioconcentration ratio of PCP in the fish and the distribution ratio of PCP in organic solvents/water at various $\mathrm{pH}$.

\section{Materials and Methods}

Distribution of PCP in Solvents/Water at Various $p H$

In this study, 1-heptanol, 1-octanol and 1-nonanol were used. Nonpolar organic solvents such as xylene, $n$-hexane and $n$-heptane were also used comparing with the above alcohols.

The distribution ratio of $\mathrm{PCP}$ between these solvents and water at $\mathrm{pH} 5.5,6,7,8,9$ and 10 were determined by the following procedure. PCP solutions $(37.5 \mu \mathrm{M})$ of $\mathrm{pH} 5.5,6,7$ and 8 were prepared as $\mathrm{M} / 50 \mathrm{Na}_{2} \mathrm{HPO}_{4}$ buffer solution and those of $\mathrm{pH} 9$ and 10 as $\mathrm{M} / 50 \mathrm{Na}_{2} \mathrm{CO}_{3}$ buffer solution by adjusting to their respective $\mathrm{pH}$ with $1 \mathrm{M}$ solution of $\mathrm{HCl}$ or $\mathrm{NaOH}$. An aliquot of the PCP solution of each $\mathrm{pH}$ was shaken with a proper amount of each organic solvent at $16-17^{\circ} \mathrm{C}$ for $15 \mathrm{~min}$. After removing emulsion in the water layer by centrifugation, the PCP concentration in the water phase was determined by the 4-aminoantipyrine

*1. Studies on the Metabolism of Chlorophenols in Fish_—XIV.

*2 Lab. Environment. Sci., Ube Jun. College, Ube 755, Japan. (等野拓男：宇部短期大学骤境衛生学科).

* Lab. Fish. Environment. Sci., Fac. Agr., Kyushu Univ., Fukuoka 812, Japan（小林邦男：九州大学曟学 部水産增殖聚境学教室). 
method $^{3)}$. The PCP concentration in the solvent phase was calculated from the amount of PCP decreased in the water phase. The distribution ratio of PCP between each solvent and water was obtained as the ratio of the PCP concentration in the solvent to that in the water.

Bioconcentration of PCP by Goldfish at Various $p H$

The experiment on the bioconcentration of PCP by goldfish exposed to PCP-media at $\mathrm{pH} 5.5,6$, $7,8,9$ and 10 has been demonstrated in the preceding paper. ${ }^{11}$

\section{Results and Discussion}

Fig. 1 shows the change in the PCP distribution ratio between each solvent and water in the $\mathrm{pH}$ range from 5.5 to 10 . The ratio in the nonpolar solvent/water system decreased logarithmically with an increase of the $\mathrm{pH}$ of aqueous phase. In the alcohol/water system, the distribution ratio also decreased almost logarithmically with an increase of $\mathrm{pH}$ in the range from 5.5 to 8 . Above $\mathrm{pH} 8$, however, the decrease of the distribution ratio in the system slowed down with an increase of pH.

Assuming that $\mathrm{PCP}$ in both the solvent and aqueous phases is monomeric and that the unionized PCP alone transfers from water to solvents, the change in the distribution ratio with varing $\mathrm{pH}$ of

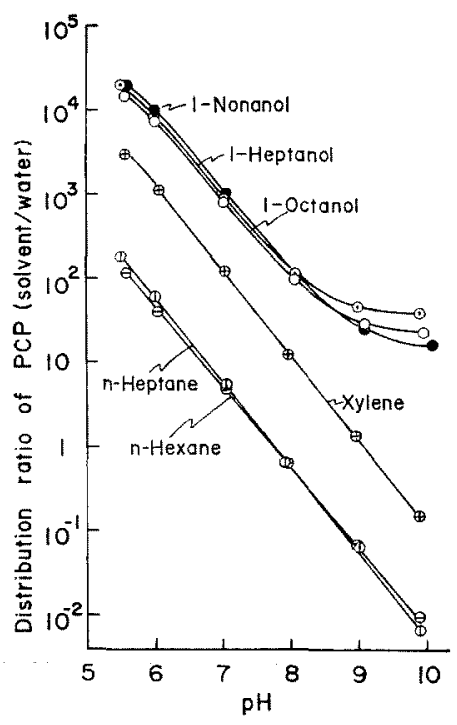

Fig. 1. Effect of $\mathrm{pH}$ on the distribution ratio of PCP in solvents/water. aqueous phase is expressed as

$$
D=P \cdot \frac{\left[\mathrm{H}^{+}\right]}{\mathrm{Ka}+\left[\mathrm{H}^{+}\right]}
$$

where $D, P$ and $\mathrm{Ka}$ are the distribution ratio, the partition coefficient and the dissociation constant, respectively. When $\mathrm{Ka} \gg\left[\mathrm{H}^{+}\right]$, the equation (1) can be expressed as

$$
D=\boldsymbol{P} \cdot \frac{\left[\mathrm{H}^{+}\right]}{\mathrm{Ka}}
$$

Taking logarithms,

$$
\log D=\log P+\mathrm{pKa}-\mathrm{pH}
$$

Since the dissociation constant of PCP, pKa, is $4.8,{ }^{4)}$ the change in the distribution ratio at $\mathrm{pH} 6$ or above can be expressed by the equation (3), resulting in a logarithmic decrease with an increase of the $\mathrm{pH}$ of aqueous phase.

The results shown in Fig. 1 demonstrate that the transfer of PCP from water to the nonpolar solvents is due to only the unionized form, following the equation (3). The transfer of PCP to the alcohols, however, is due to not only the unionized PCP but also partly the ionized form, resulting in the slow decrease of the distribution ratio in each alcohol/water system at the $\mathrm{pH}$ above 8 slipping off the equation (3).

The concentration of the ionized and unionized PCP ( $C i$ and $C n$ ) in dilute aqueous solution can be expressed by the equations (4) and (5), respectively.

$$
\begin{gathered}
C i=\frac{C \cdot \mathrm{Ka}}{\mathrm{Ka}+\left[\mathrm{H}^{+}\right]} \\
C n=\frac{C \cdot\left[\mathrm{H}^{+}\right]}{\mathrm{Ka}+\left[\mathrm{H}^{+}\right]}
\end{gathered}
$$

where $C$ is the concentration of total PCP.

Table 1 shows the degree of ionization of PCP in dilute aqueous solution at various $\mathrm{pH}$, which was calculated theoretically by equations (4) and (5).

The contribution of the ionized and unionized forms of PCP to the distribution ratio was examined by relating the proportions of both forms (Table 1) to the PCP distribution ratios in octanol/water and hexane/water (Fig. 2). In Fig. 2, the broken line for octanol is based on the assumption that the unionized form alone transfers from the aqueous phase to the solvent. According to this assumption, the distribution ratio attributed to the unionized form in this system must be 0.75 at $\mathrm{pH}$ 10. The contribution of the ionized form to the distribution ratio at $\mathrm{pH} 10$ is derived as 21.7 by 
Table 1. The degree of ionization of PCP at various $\mathrm{pH}$

\begin{tabular}{ccc}
\hline \multirow{2}{*}{$\mathrm{pH}$} & \multicolumn{2}{c}{ Percent of PCP } \\
\cline { 2 - 3 } & Unionized form & Ionized form \\
\hline 5.5 & 16.78 & 83.22 \\
6 & 6.67 & 93.33 \\
7 & 0.67 & 99.33 \\
8 & 0.067 & 99.933 \\
9 & 0.0067 & 99.9933 \\
10 & 0.00067 & 99.99933 \\
\hline
\end{tabular}

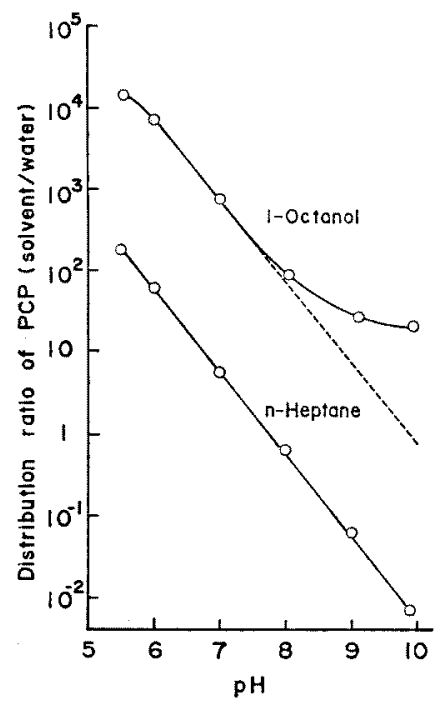

Fig. 2. The distribution ratio of PCP in 1-octanol/ water and $n$-heptane/water at various $\mathrm{pH}$.

subtracting that of the unionized form, 0.75 , from the distribution ratio of total PCP found as 22.4.

The contribution of the ionized form to the distribution ratio at $\mathrm{pH} 5.5$ was calculated as follows: $21.7 \times 83.22 / 99.999=18.0$, where 21.7 is the contribution of the ionized form to the distribution ratio at $\mathrm{pH} 10$ as described above, and 83.22 and 99.999 are percent of the ionized form at $\mathrm{pH}$ 5.5 and 10, respectively, as shown in Table 1.

Table 2 shows the contributions of the ionized and unionized forms to the distribution ratio in octanol/water at various $\mathrm{pH}$, which were obtained by the calculation in the same procedure as described above. The contribution of the unionized form to the distribution ratio was derived by subtracting that of the ionized form from the distribution ratio found at each $\mathrm{pH}$. The $\mathrm{pH}$ dependence of the contribution of the unionized form to the distribution ratio in octanol/water showed
Table 2. Effect of $\mathrm{pH}$ on the distribution ratio of PCP in 1-octanol/water and the contribution of the unionized and ionized forms to the ratio

\begin{tabular}{lccc}
\hline pH & $\begin{array}{c}\text { Distribution } \\
\text { ratio }\end{array}$ & \multicolumn{2}{c}{$\begin{array}{c}\text { Contribution to } \\
\text { distribution ratio }\end{array}$} \\
\cline { 3 - 4 } & & $\begin{array}{c}\text { Unionized } \\
\text { form }\end{array}$ & $\begin{array}{c}\text { Ionized } \\
\text { form }\end{array}$ \\
\hline 5.5 & 14300 & 14282 & 18.0 \\
6 & 7550 & 7530 & 20.3 \\
7 & 770 & 748 & 21.6 \\
8 & 95.6 & 74.9 & 21.7 \\
9 & 29.0 & 7.3 & 21.7 \\
10 & 22.4 & 0.75 & 21.7 \\
\hline
\end{tabular}

the same tendency as that in the nonpolar solvents/ water, demonstrating the rationality of the assumption that the contribution of the unionized form to the distribution ratio is 0.75 at $\mathrm{pH} 10$.

Although in the alcohol/water system, the contribution of the ionized form to the distribution ratio is almost negligibly small at $\mathrm{pH} 7$ or below as compared with that of the unionized form, it relatively increases with an increase of $\mathrm{pH}$, because the proportion of the unionized form decreases logarithmically by its conversion to the ionized form, as shown in Table 1. Therefore, the contribution of the ionized form to the distribution ratio,

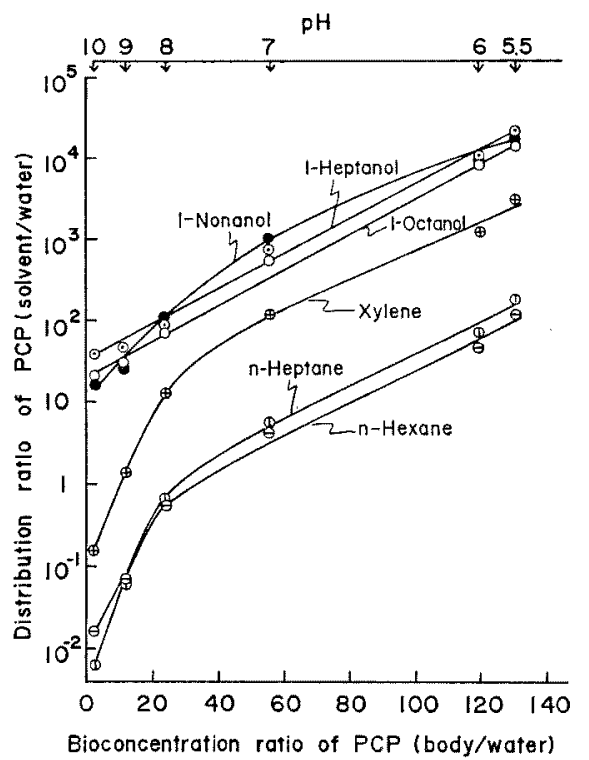

Fig. 3. Relationship between the distribution ratio of PCP in organic solvents/water and the bioconcentration ratio of $\mathrm{PCP}$ in goldfish at 1 -h exposure to $0.1 \mathrm{ppm} \mathrm{PCP}$ at various $\mathrm{pH}$. 
which is attributed to the formation of hydrogenbond with alcohol, must be taken into consideration in the polar organic solvent/water partitioning system at the high $\mathrm{pH}$.

Fig. 3 shows the relationship between the distribution ratios of PCP in each solvent/water in the $\mathrm{pH}$ range from 5.5 to 10 shown in Fig. 1 and the bioconcentration ratios of $\mathrm{PCP}$ in goldfish at $1-\mathrm{h}$ exposure to $0.1 \mathrm{ppm}$ PCP-media, which were 131 , $120,56,24,12$ and 2 at pH 5.5, 6, 7, 8, 9 and 10 , respectively, as reported in the preceding paper. ${ }^{1)}$ The linear relationship was observed in heptanol and octanol in the $\mathrm{pH}$ range studied, but not in the nonpolar solvents at $\mathrm{pH} 8$ or above. In nonanol, a similar tendency to that in the nonpolar solvents was observed, owing to its lower polarity as compared with those of heptanol and octanol.

The $\mathrm{pH}$-dependent linear relationship between the bioconcentration ratio in the fish and the distribution ratio in the alcohol/water system demonstrates that the transfer of PCP from media to the fish is caused mainly by passive diffusion of the unionized form probably through the gill membrane, as illustrated by SCHANKER ${ }^{\text {b) }}$ and BRODIE ${ }^{\text {() }}$ in their $\mathrm{pH}$-partition theory on the transport of chemicals across biological membranes such as stomach, intestine and so on, and that the reduction of the toxicity of PCP to the fish with an increase of the $\mathrm{pH}$ of media is attributed to the decrease of the concentration of the unionized PCP in the media by conversion into the ionized form, although the ionized PCP is slightly transferred to the fish presumably by hydrogen-bonding with polar lipids such as phosphatidylcholine and so on which constitute the gill membrane.

According to VerrH et al.,7) the logarithms of the bioconcentration factor and 1-octanol/water partition coefficient are linearly correlated in almost all the organic chemicals tested, but the addition of a polar functional group, such as hydroxyl group, to the chemicals substantially reduces the bioconcentration factor. For example, the logarithm of the bioconcentration factor for PCP in fathead minnow, Pimephales promelas, was only 2.89 , whereas the logarithm of the partition coefficient for PCP was 5.01.?

As shown in Table 2, however, the distribution ratio of PCP in 1-octanol/water at $\mathrm{pH} 7$ in this experiment was 770 in good agreement with the bioconcentration factor for PCP in fathead minnow." These results indicate that the estimation of the bioconcentration factor of organic chemicals, particularly having polar functional groups, in fish by partitioning in octanol/water should be based on the distribution ratio at the normal $\mathrm{pH}$ for fish rather than the partition coefficient which was proposed by NeELY et al. ${ }^{2)}$

\section{Acknowledgement}

This study was partly supported by a grant from the Ministry of Education.

\section{References}

1) K. Kobayashi and T. Kishino: Bull. Japan. Soc. Sci. Fish., 46, 167-170 (1980).

2) W. E. Neely, D. R. Branson, and G. E. Blau: Environ. Sci. Technol., 8, 1113-1115 (1974).

3) K. Kobayashi, H. Akrtake, and T. Tomiyama: Bull. Japan. Soc. Sci. Fish., 35, 1179-1183 (1969).

4) G. E. Blackman, M. H. Parke and G. Garton: Arch. Biochem. Biophysics, 54, 45-54 (1955).

5) L.S. SChanker: Ann. Rev. Pharmacol., 1, 2944 (1961).

6) B. B. Brodie: in "Absorption and Distribution of Drugs" (ed. by T. B. BinNs), E and S Livingstone Ltd., Edinburgh and London, 1964, pp. 1648.

7) G. D. Veith, D. L. Defoe, and B. V. Bergstedt: J. Fish. Res. Board Can., 36, 1040-1048 (1979). 